\title{
Organization of Transport in a Commercial Enterprise Operating in a Branch Purchasing Group
}

\author{
GRZEGORZ ZIMON \\ Rzeszow University of Technology, Budynek S, Aleja Powstańców Warszawy 10, 35-959 Rzeszów, \\ Poland.E-mail:gzimon@prz.edu.pl
}

\begin{abstract}
Joint action in multi-stakeholder organizations is one of the ways to improve the competitive position of enterprises. A standard example of multi-entity organizations are group purchasing organizations (GPOs). In purchasing groups companies often order goods or materials with excessive stock which adversely affects the level of inventory and transport costs. However, cooperation between enterprises and mutual transactions provide opportunities for optimizing the level of supply and costs related to transport. In the article some possibilities of transport organization obtained by enterprises operating in purchasing groups were presented. The main goal of the article is to present the optimal model of transport organization in a commercial enterprise operating in the branch purchasing group.
\end{abstract}

Keywords: Logistics, Transport, a GPO.

\section{Organización del transporte en una empresa comercial que opera en un grupo de compras de la industria}

\section{RESUMEN}

La acción conjunta en las organizaciones de múltiples partes interesadas es una de las formas de mejorar la posición competitiva de las empresas. Un ejemplo estándar de organizaciones multi-entidad son grupos de compras. En los grupos de compras, las empresas a menudo ordenan bienes y materiales con existencias excesivas, lo que afecta negativamente el nivel de inventario y los costos de transporte. Sin embargo, la cooperación entre empresas y las transacciones mutuas brindan oportunidades para optimizar el nivel de suministro y los costos relacionados con el transporte. El artículo presenta las posibilidades de organización del transporte obtenidas por empresas que operan en grupos de compras. El objetivo principal del artículo es presentar un modelo óptimo de organización del transporte en una empresa comercial que opera en el grupo de compras de la industria.

Palabras claves: Logística, transporte, el grupo de compras.

JEL classification: L10, R40, G30

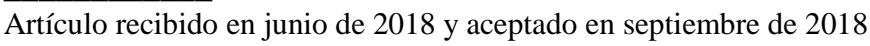

Artículo disponible en versión electrónica en la página www.revista-eea.net, ref. ə-36315 


\section{INTRODUCTION}

Purchasing groups are organizations that usually gather small and mediumsized enterprises. They are created in every industry and are designed to strengthen the competitive position of enterprises in the market. The benefits of companies operating in purchasing groups can be divided into four basic groups. The first and the most important of them is the low price of purchased goods, materials or services. The purpose of the formation of purchasing groups are joint purchases and thanks to the implementation of joint purchases and the use of economies of scale companies operating in purchasing groups can achieve this goal. Low price of purchased goods and materials allows reducing costs in the item consumption of materials or the value of sold goods and materials at the purchase price which will positively affect the profitability of enterprises and the financial result.

The second basic benefit that should be obtained by enterprises operating within purchasing groups is a beneficial commercial credit. Trade credit appears in most transactions. Its length has a huge impact on the financial security of the company. It allows building a receivables management policy which has a large impact on the level of sales. The third advantage of functioning within purchasing groups is a possibility of reducing the costs of purchased services. The last group of benefits is the increase in the level of sales which should be caused by the low price of purchased goods and favorable trade credits offered by a company. Low price and attractive credit are the most important elements that the contractors pay attention to. If companies operating in purchasing groups want to obtain all these benefits they need to manage logistics efficiently and, in particular, organize distribution logistics.

The aim of the article is to present the model of transport functioning in an enterprise operating in the branch purchasing group. Purchasing groups are usually associated with joint purchases and the use of economies of scale. It often happens that a group needs a discount from the producer to reach a specified level of purchase. Purchasing group managers set purchase limits that need to be completed to achieve a given discount. In this case, the amount may exceed the actual demand for the given range. The company purchases with a large margin which does not have a positive impact on the logistics costs, i.e. storage or transport. Functioning in purchasing groups should to a large extent be based on cooperation. Lack of cooperation is a serious mistake whose effect may be the lack of the possibility of using tools that provides joint functioning within multi-entity groups. Enterprises that work with each other have several options for arranging deliveries. They can create their own transport organization system. However, before that they should create an appropriate system for recording transport costs, which will provide them with information in which area one can 
look for cost reduction and, above all, this system will help them to control the incurred costs.

In the article, on the example of the Polish branch purchasing group, the model of transport organization for enterprises operating in this type of units was presented In the article the principles of the functioning of purchasing groups, the system of recording transport costs, methods of organizing the supply and distribution of goods and materials were featured.

\section{GROUP PURCHASING ORGANIZATIONS}

Group purchasing organizations are a very popular form of business unit all over the world. Group shopping and purchasing groups are methods that have been known for a long time already. Group shopping was already popular in ancient Egypt (Wooten 2003, pp.4-7 ). The most important benefit that appears in purchasing groups is caused by scale effects. The purchasing group is an entity using collective purchasing power to obtain a discount (Yang et al., 2017, pp.581589). A purchasing group can be defined as a group of cooperating companies that jointly controls and improves material, information and monetary flows from suppliers to final recipients. Participants of such a system form a separate central unit whose main task is to achieve the goals set by enterprises operating in a given system (Zimon 2018, pp.87-104). In this type of literature purchasing groups are referred to as groups of third parties. The third party is a profit-oriented organization or a non-profit organization that may be owned by the members of the group (Schontanus Telegen 2007, pp.53-68 ). The most common functioning of group purchasing organizations (GPO) worldwide can be observed in the healthcare sector (Nollett et al., 2017, pp.17-27). In the United States hospitals organize about $70 \%$ of purchases through the GPOs (Safaei et al., 2017, pp. 8290). In recent years, purchasing groups have also dominated purchases of pharmaceuticals (pharmacies) and other medical supplies. (Marvel , Yang 2008, pp.1090-1105). There are hundreds of GPOs operating in healthcare in America (Hu et al., 2012, pp.7-23). The operation within purchasing groups is also based on trust. Enterprises in purchasing groups should cooperate and support themselves in difficult moments. Lack of cooperation, lack of information exchange, experience is the first sign informing about a bad situation within the group. Enterprises operating in such a way should be eliminated because, apart from the sales volume, they do not contribute anything that would increase the purchasing power of the group. In their research, the authors, as the most important benefits offered by functioning in purchasing groups, mention a reduction in the prices of purchased goods (Tella, Virolainen 2005, pp.161-168 ), reduction of administrative costs (Nollet, Bealulieu 2005, pp.11-17 ). The sales department costs are also reduced. The latter position, namely selling costs is strongly connected with distribution logistics, where the transport department 
plays a very important role. Joint functioning should therefore have a positive impact on and optimize the costs level of this department.

Joint operations should also improve the financial security of enterprises through the use of reciprocal transactions. Lack of liquidity is a basic risk factor, so one should look for solutions that will allow controlling its level. (Racicot, Rentz, 2018, pp. 251-262)

In the case of purchasing group management analysis, it is important to divide purchasing groups into branch and multi-branch ones. A detailed division of purchasing groups is presented in the figure below. The details are shown in Figure 1.

Figure 1

Classification of group purchasing organizations

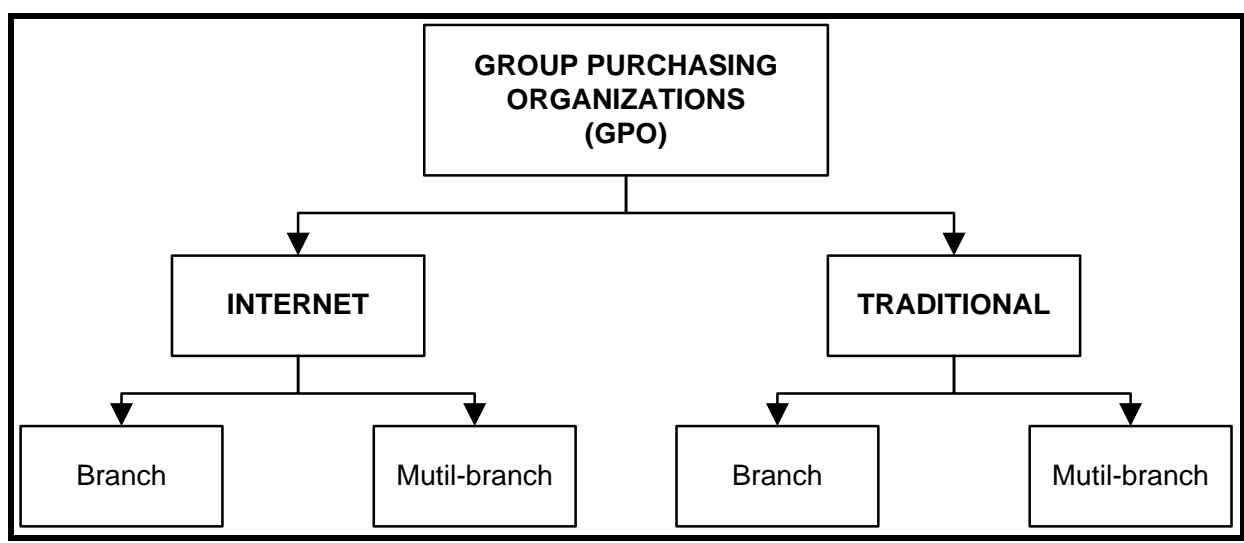

Source: Zimon G., Płynność finansowa w przedsiębiorstwach tworzących grupy zakupowe, [in] Zarządzanie finansami firm- teoria i praktyka ( ed. A.Kopiński, P. Kowalik ), Prace Naukowe Uniwersytetu Ekonomicznego we Wrocławiu 321, Wrocław 2013, p. 213

The division of groups into branch and multi-branch ones is very important as it has a big impact on the group's purchasing power. In groups where companies from one industry operate, purchases are made with several suppliers, there are no divisions, the purchasing power is high. The central unit of the purchasing group deals with one group of suppliers, which facilitates the functioning of such an organization. In multi-branch groups purchases are made with different suppliers, enterprises are divided into smaller groups and make purchases from different suppliers. These divisions reduce the economies of scale which is disadvantageous for enterprises. Purchasing groups can also be divided according to the type of integrating unit. The first division is the Internet and traditional division. It is also important whether the integrator is internal or external. The internal one is a unit created by all companies operating in a group. This is the best solution because such an integrator will not be focused on generating profits 
for itself. It gains a lot of trust because individual companies have a direct impact on its operation. An external integrator is a unit that searches companies for its own organization, determines monthly fees and is set to generate a certain amount of profit. Such a central unit is primarily focused on achieving profits and the managers primarily try to provide funds for the functioning of their own enterprise. Enterprises in these types of groups do not have a big influence on the decision-making process in such an organization.

In turn, in groups with an internal integrator, when financial problems arise, companies operating in a group may improve the financial situation of the central unit by increasing fees. After the financial crisis, the pace of development of particular areas of the regions is very different, there are some gaps (Duarte Santos et al., 2017, pp. 629-652). Purchasing groups are a chance for small enterprises to compensate for these differences. Thanks to their functioning enterprises are able to resist competitors.

\section{RECORDS OF COSTS OF THE TRANSPORT DEPARTMENT IN A COMMERCIAL ENTERPRISE}

The functioning of transport departments in an enterprise will slowly disappear. This is due to the costs that are incurred in relation to their ownership. In the case of trading enterprises the system of cost accounting on accounts of group no. 4 is generally used. Group accounts No. 4, i.e. costs by type, include:

- Amortization, depreciation write-offs regarding fixed assets and intangible assets,

- Consumption of materials and energy, it groups the costs of used basic and auxiliary materials, fuels, packaging, office supplies, magazines, etc.,

- External services, costs of works and services provided by other entities to the company, e.g. transport services, lease services, leases, banking and IT services,

- Taxes and fees, costs of stamp and administrative fees, notarial fees, court fees, tax on means of transport, real estate tax, tax on goods and services not deductible,

- Wages, salaries or benefits in kind paid to employees of the entity under employment contracts, contracts of mandate, contracts for specific tasks and others,

- Insurance and other benefits, costs of social insurance contributions in the part paid by the employer, costs of contributions to the obligatory Labor Fund, Guaranteed Employee Benefits Fund, Bridging Pensions Fund, and training costs for employees, deductions for the company social benefits fund, costs for behavior health and safety at work, 
- Other costs by type are other costs that cannot be included in the groups described above, e.g. employee travel expenses, representation costs, advertising costs.

In the case of distribution and transport logistics costs, the account plan should be more developed. For accounts, consumption of materials should include auxiliary accounts, such as fuel consumption, consumption of oils and lubricants, etc. It is also worth introducing an account of group five informing about cost centers. This group includes costs of sales, management, primary production, costs of intermediate production departments and auxiliary production. The extension of the registry system with these costs will allow determining what type of costs and in which area of the enterprise is borne. An exemplary chart of the cost of fuel consumption in the transport department is shown in the chart below.

Figure 2

A simplified diagram of the full cost record of the transport department

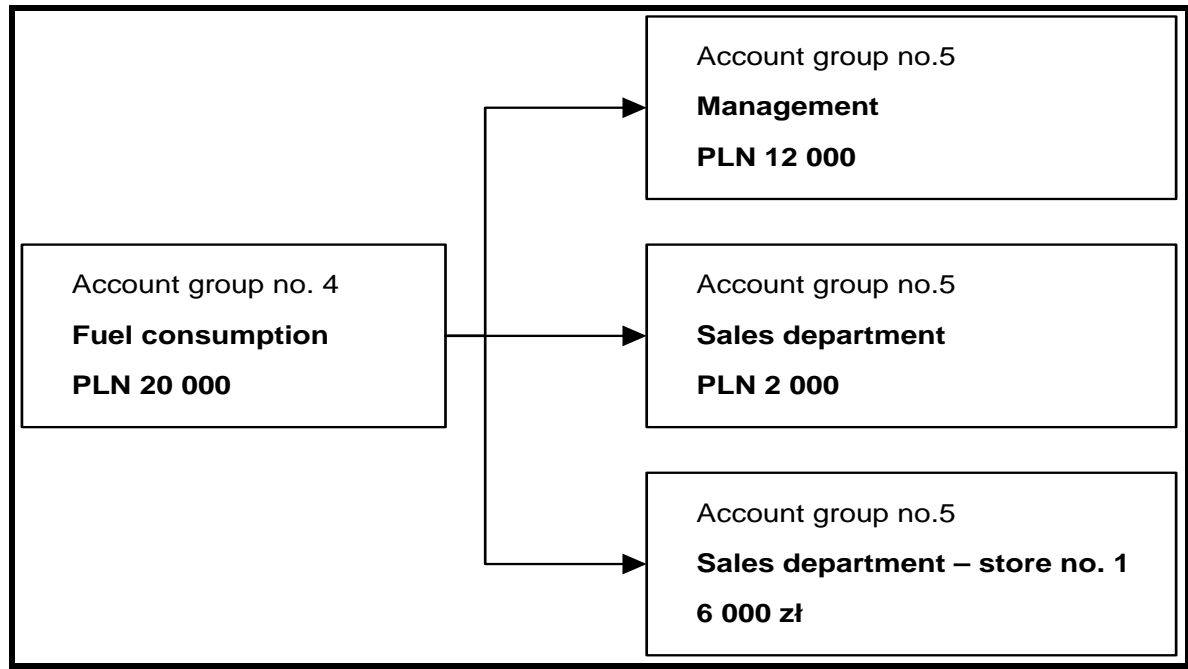

Source: Auhtor's own research.

A separate set of accounts should be created for each transport unit. In the case of trade enterprises, the most important share of costs are external services, remuneration, insurance and fees, and fuel consumption. In order to improve the control of these costs, it is worth using the accounts of group no. 5. However, one should first of all make a more detailed division of costs in a generic manner. The details are shown in chart 2. 
Figure 3

Extended scheme for generic costs recording in a transport department

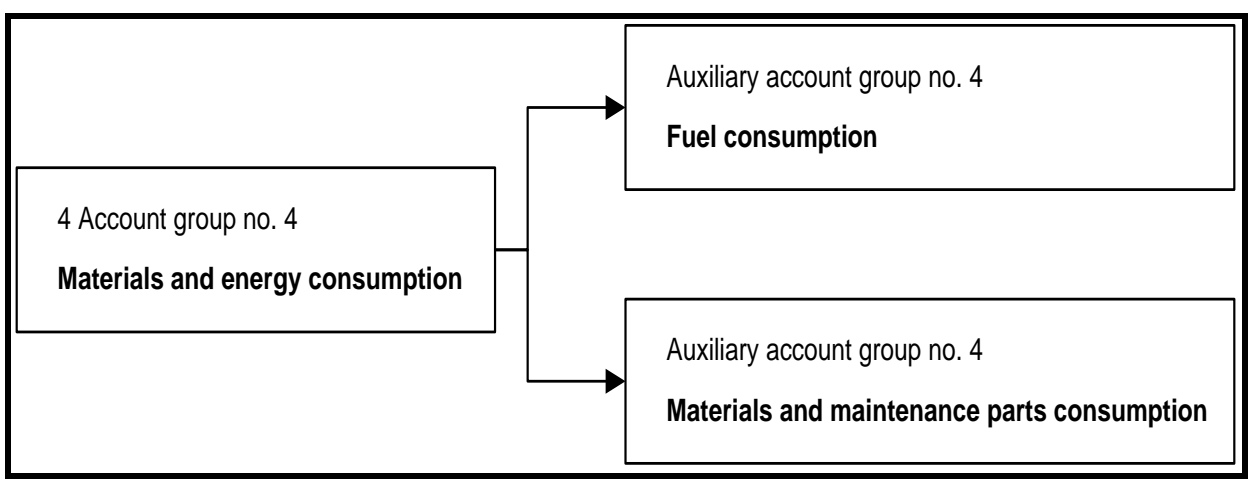

Source: Auhtor's own research.

The use of an extended system of recording transport costs will help managing costs control and lead to optimization of the level at the transport department.

The cost of remuneration is a big problem when managing transport costs. The problem is that in the case of employees' wages there are certain wage rates that an employee must receive. As far as fuel costs are concerned, the management of the business has no influence on the price of oil in the world. However, they can negotiate better prices for the entire group compared to the price they receive for single enterprises. The remaining costs of the transport department can also be reduced by operating within purchasing groups.

\section{MATERIALS AND METHODS}

In order to present the model of supply organization for enterprises operating in branch purchasing groups, financial data from 24 enterprises were used. These companies operate in the oldest and largest commercial trade group in Poland. The annual turnover that generates this range is from PLN 20 million to PLN 70 million. The data on costs came from profit and loss accounts from 2017. A preliminary cost analysis was made to present transport costs.

\section{MODEL OF TRANSPORT ORGANIZATION IN A PURCHASING GROUP}

An organization of transport, delivery or shopping in an enterprise has a big impact on maintaining sales continuity. Delays in this area have a negative impact on the level of financial liquidity and sales volume. An empty warehouse in a situation when a contractor appears means lost sales opportunities. Therefore, it is very important to create such a model of transport organization in order to 
positively influence on the two most important elements informing about the strength of the company, such as sales volume and liquidity level.

In order to optimize costs, the company managers often decide to liquidate the transport department and rely on external services in this area (outsourcing). In small and medium-sized enterprises the cost level of maintaining the transport department is not high. When analyzing the costs of enterprises operating in the Polish branch purchasing group, it was established that the share of transport costs is between $15 \%$ and $20 \%$. In an example of a commercial enterprise operating in a branch purchasing group the share of costs of the transport department in logistics costs is about $20 \%$. It is, therefore a low level of costs incurred since the average share of logistics costs in total costs is about $15 \%$. Table 1 presents the detailed division of the costs incurred by the transport department for enterprises operating in branch purchasing groups. The table presents average results for all enterprises for 2017 divided into types of costs.

Table 1

Costs structure of transport department in 2017

\begin{tabular}{|l|c|}
\hline \multicolumn{1}{|c|}{ Types of costs } & Transport costs \\
\hline Drivers' salary along with overheads & $\mathbf{2 8 \%}$ \\
\hline External transport & $66 \%$ \\
\hline Others costs & $6 \%$ \\
\hline Total & $\mathbf{1 0 0} \%$ \\
\hline
\end{tabular}

Source: Auhtor's own research.

When analyzing Table 1 it can be noticed that the costs associated with delivering goods to the "doors" are mainly foreign services - external transport. In the analyzed unit, virtually own transport was abandoned and transport services were outsourced to external companies. Own transport is performed to the most important key contractors. Their loss may constitute a large cost for enterprises. Costs related to fuel consumption constitute a small share in the structure of costs incurred. However, the following question arises: what is more important for managers - costs reduction or the quality of services provided.

The maintenance of the transport department costs but the expenses incurred make it possible to earn revenues. In purchasing groups the transport department plays a special role as it allows an access to missing goods in an emergency situations. In the case of purchase and delivery of goods, enterprises operating in purchasing groups have several options.

In GPOs with the central warehouse the delivery organizations can be divided into five options:

- Direct deliveries. This delivery system is only possible when ordering the right size of a range set by the central unit. The central unit is omitted, the 
delivery straight from the producer's warehouse goes to the company. The direct delivery system does not incur high transport and ordering costs. Another positive feature is the speed of delivery. The speed and practically no transport costs are the advantages for this solution. However, this type of delivery of goods is possible in the case of large supplies. This system skips the central unit, (Zimon 2015, p. 7058-7059)

- Deliveries using the central unit of the purchasing group. The central unit delivery system is a solution for companies that did not join a joint purchase at the time of submitting a product offer or if they had ordered a small amount of goods or special items that were delivered to the central warehouse. From the central warehouse, individual companies download the assortment. The major disadvantage of this system are the costs to be borne, i.e. transport costs and maintenance costs of the inventory in the central office (Zimon 2018, p.87-104).

- Combined deliveries. This supply model appears when a given batch of goods goes to an area where several companies in a particular GPO exist. Combined deliveries are based on the Milk-Run concept and occur when loads are too small to justify direct deliveries. ( Krawczyk, 2011, p.167 )This system (moderate supply management strategy) appears as it was in the early case when supplies were smaller. The manufacturer sent a delivery to several customers who were unloaded in successive locations (businesses). Storage, ordering, transportation costs are low.

- Delivery without the manufacturer. The last system is the most expensive one that can be defined as aggressive supply management strategies. The central unit in the GPO purchases the goods for themselves. Companies buy goods from the central warehouse. If there is a demand for the item in the central unit, the company can order it. This action should be used when it is slowly becoming a shortage of inventory or in unexpected situations when there are unexpected shortcomings for various reasons. This supply system is the most expensive as the central unit raises the price of the product. For the central unit, the purchase of goods in their own warehouse, with the intention of reselling them, is an investment of surplus cash. (Zimon 2018, p. 87-104)

- Deliveries from enterprises operating within the purchasing group.

The latter system can be effectively applied only when there is a transport department in the company.

Many companies eliminate transport departments and start using external transport. Such a management policy has a positive impact on costs because it leads to a reduction of costs related to remuneration, benefits for employees, costs related to maintaining the transport base. However, the quality of services is 
deteriorating. The transport unit operating in the company is prepared to provide services to contractors. In the case of services provided by this department, the customer counts, not the time or place of delivery. The employees of the transport department are flexible to the offer of the recipient, have time, can change the place of delivery, usually know their contractors for some time, which makes cooperation much easier. The main task of the transport department is to provide high-quality services to maintain the contractor. In an enterprise operating in a branch purchasing group, the organization of transport largely affects financial security and the level of sales.

When there is a need to replenish stock, the company can quickly replenish its inventory by purchasing goods from another unit operating in the purchasing group. Having its own transport can quickly deliver goods to the contractor. Such a management policy of the transport department based on the delivery of goods on the Just in time basis has a positive impact on the liquidity and financial security of enterprises. Thanks to such replenishment, there are no costs of lost opportunities in the company. There is no risk regarding the loss of a contractor, which has a positive effect on the level of sales.

The transport department appears in operations related to the purchase and, above all, sales. The details are presented in Figure 4.

Figure 4

The model of operation of the transport department in an enterprise operating in the purchasing group

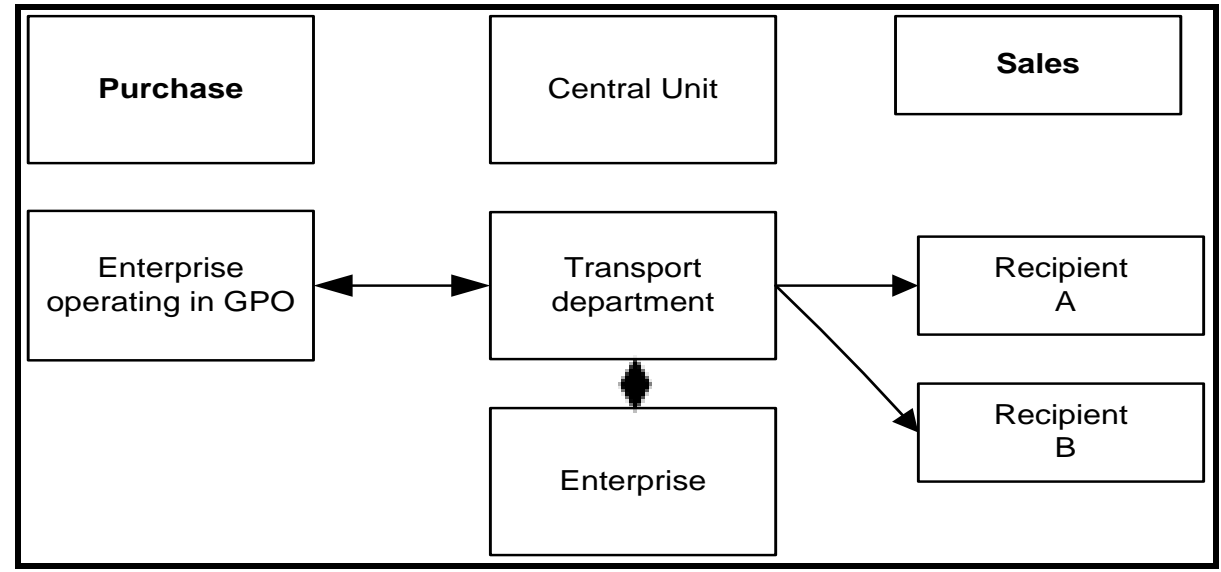

Source: Auhtor's own research.

The model presented in Figure 4 shows exactly where it is worth supporting logistics with its own transport. 
In the case of purchase, it is worth using the transport department in an emergency in a situation where there is a need to replenish the inventory. The transport department is then able to deliver the goods to the destination and not only to the headquarters of the company. The internal department of transport of this type of transactions is able to realize faster than external transport companies. Mutual transactions concerning the purchase of goods from enterprises operating in the purchasing group take place only when companies operate in the same area, e.g. the same city. Otherwise, it is worth completing the stocks directly in the warehouse of the purchasing group's central unit and here the transport department also appears.

The role of the transport department in the sales process is very important.

When creating a transport organization model in a branch purchasing group, it is worth dividing the recipients into individual groups. Group A includes the earliest contractors for the company, and the remaining companies qualify for group B. Deliveries of goods to companies from group A are carried out through the use of the transport department. Counterparties belonging to group A are the key to the functioning of the company. The transport department realizes deliveries to permanent important recipients who are treated in a special way. Such a policy of supply management should be well received by enterprises classified in group A. In the case of deliveries by external transport companies for the supplier, the time and place of delivery is very important. The supplier wants to deliver the goods on time, and is not interested in additional waiting for the recipient, change in delivery time, space or assistance in unloading. Managers are tasked to make every effort to ensure that the recipient is satisfied, therefore maintaining the transport department is very important. It is an element that should positively distinguish the company from the others. The costs of maintaining the transport department are a disadvantage of this policy. However, in the scale of costs of the entire company, they do not constitute a large share. Group B suppliers are in turn served by transport companies from the outside, the transport department has an opportunity to relate to significant customers from the B group.

\section{CONCLUSIONS}

If an enterprise decides on its own transport department, there will be costs of its maintenance. However, when assessing their level in the structure of the analyzed enterprises, the share of these costs in total costs is a small amount. The operation within the purchasing group means a different type of organization of supplies of goods and materials. The transport department helps reduce the risk of inventory shortages and sales stopovers. It is possible thanks to the mutual transactions presented in the model between the participants of purchase groups and the central unit of the purchasing group. The transport department efficiently 
implements them. These activities allow avoiding the cost of a significant opportunity resulting from downtime in sales, because there are no such stopovers.

The presented model of the functioning of the transport department also has a positive impact on the relations with the recipients. Deliveries of goods to trusted contractors are carried out by the well-known transport department that delivers the goods always on time and to the place that is very beneficial for contractors. However, when a company is looking for opportunities to reduce logistics costs, using its own transport is not a good solution. The use of external services will be a better solution.

In the case of branch purchasing groups the managers do not have to liquidate the internal transport department because a good solution leading to cost optimization is an introduction of appropriate control systems of the transport department. Appropriate cost accounting systems appear here. It is worth keeping records with the use of group accounts 4 and 5 in commercial enterprises. Also, generic costs should be properly divided into additional subgroups, e.g. consumption of materials and energy for fuel and materials and spare parts. These activities allow a detailed analysis of the costs of the transport department and allow finding areas where one can apply group purchases for the transport department to reduce costs. In the case of purchasing groups the use of economies of scale and joint purchase of materials, spare parts related to the operation of the transport department also have a positive impact on the level of incurred costs.

The presented cost analysis showed that external services and material consumption constitute a large part of the cost structure and these are positions where collective group purchases are able to reduce them. Managers have to decide whether to choose a policy to cut costs only, or to take advantage of the opportunities that are granted to companies operating within purchasing groups and to create a model of transport organization with their own transport department. Functioning together in a group and owning the own transport department allows limiting the occurrence of stopovers for sale, it also gives more opportunities to organize deliveries and allows you to apply your own distribution system for key counterparts. These actions allow reducing costs, do not cause stopovers in sales, which positively affects the continuity and level of sales revenues.

\section{BIBLIOGRAPHY REFERENCES}

DUARTE SANTOS, A., RIBEIRO S., CASTELA, G., TAVARES DA SILVA, N. (2017). "The Dynamics between Economic Growth and Living Standards in EU Countries: A 
STATICO Approach for the Period 2006-2014". Estudios de Economía Aplicada, vol. 35(3) pp. 629-652.

HU, Q. , SCHWARZ, L. B. , \& UHAN, N. A. (2012). "The impact of group purchasing organi-zations on healthcare-product supply chains". Manufacturing \& Service Operations Management, 14(1), pp. 7-23

KRAWCZYK S. (2011). Logistyka. Teoria i praktyka. Tom 2, Difin, Warszawa

MARVEL H., \& YANG H., (2008). "Group purchasing, nonlinear tariffs, and oligopoly". International Journal of Industrial Organization 26(2008), pp. 1090-1105

NOLLET, J., BEAULIEU M, \& FABBE-COSTES N. (2017). "The impact of performance measurement on purchasing group dynamics: The Canadian experience". Journal of Purchasing \& Supply Management 23(2017), pp.17-27.

NOLLET, J., \& BEAULIEU, M. (2005). "Should an organization join a purchasing group?" Supply Chain Management. 10(1), pp.11-17.

RACICOT, F-E., RENTZ, W.F. (2018). "Does Illiquidity Matter? An Errors-in-Variables Perspective". Estudios de Economía Aplicada, Volume 36(1), pp. 251-262.

SAFAEI A.S, HEIDARPOOR F., PAYDAR M.M, (2017). "A novel mathematical model for group purchasing in healthcare". Operations Research for Health Care 15(2017), pp. 82-90.

SCHOTANUS, F., \& TELEGEN, J. (2007). "Developing a typology of organizational forms of cooperative purchasing". Journal of Purchasing \& Supply Management, Volume 13, pp. 53-68.

TELLA E., VIROLAINEN, V.M. (2005). "Motives behind purchasing consortia". International Journal of Production Economics, pp.161-168.

WOOTEN B., (2003). "Cooperative purchasing in the 21st century". Inside Supply Management, 14(2), pp. 4-7.

YANG, Y.C., CHENG, H.K., DING, C., \& LI S. (2017). "To join or not to join group purchasing organization: A vendor's decision". European Journal of Operational Research, 258(2). DOI: 10.1016/j.ejor.2016.08.069

ZIMON, G. (2015). "Organization of goods supply in the marketing and purchasing group". Logistyka, No. 4. pp. 7058-7059.

ZIMON, G. (2018). "Influence of group purchasing organizations on financial situation of Polish SMEs". Oeconomia Copernicana, Volume 9, Issue 1, March 2018. pp.87-104

ZIMON, G. (2013). Płynność finansowa w przedsiębiorstwach tworzących grupy zakupowe, [in] Zarządzanie finansami firm- teoria i praktyka. Ed. A.Kopiński, P. Kowalik), Prace Naukowe Uniwersytetu Ekonomicznego we Wrocławiu 321, Wrocław 2013, pp. 213-220. 
